\title{
Article \\ New Glycosylated Dihydrochalcones Obtained by Biotransformation of 2'-Hydroxy-2-methylchalcone in Cultures of Entomopathogenic Filamentous Fungi
}

\author{
Agnieszka Krawczyk-Łebek*(D), Monika Dymarska (D), Tomasz Janeczko (D) and Edyta Kostrzewa-Susłow *
}

check for updates

Citation: Krawczyk-Łebek, A.; Dymarska, M.; Janeczko, T.; Kostrzewa-Susłow, E. New Glycosylated Dihydrochalcones Obtained by Biotransformation of 2'-Hydroxy-2-methylchalcone in Cultures of Entomopathogenic Filamentous Fungi. Int. J. Mol. Sci. 2021, 22, 9619. https://doi.org/ 10.3390/ijms22179619

Academic Editor: Barbora Szotáková

Received: 29 July 2021

Accepted: 1 September 2021

Published: 5 September 2021

Publisher's Note: MDPI stays neutral with regard to jurisdictional claims in published maps and institutional affiliations.

Copyright: (c) 2021 by the authors. Licensee MDPI, Basel, Switzerland. This article is an open access article distributed under the terms and conditions of the Creative Commons Attribution (CC BY) license (https:/ / creativecommons.org/licenses/by/ $4.0 /)$.
Department of Chemistry, Faculty of Biotechnology and Food Science, Wrocław University of Environmental and Life Sciences, 50-375 Wrocław, Poland; monika.dymarska@upwr.edu.pl (M.D.); tomasz.janeczko@upwr.edu.pl (T.J.)

* Correspondence: agnieszka.krawczyk-lebek@upwr.edu.pl (A.K.-Ł.); edyta.kostrzewa-suslow@upwr.edu.pl (E.K.-S.)

\begin{abstract}
Flavonoids, including chalcones, are more stable and bioavailable in the form of glycosylated and methylated derivatives. The combined chemical and biotechnological methods can be applied to obtain such compounds. In the present study, 2'-hydroxy-2-methylchalcone was synthesized and biotransformed in the cultures of entomopathogenic filamentous fungi Beauveria bassiana $\mathrm{KCH} \mathrm{J} 1.5$, Isaria fumosorosea $\mathrm{KCH} \mathrm{J} 2$ and Isaria farinosa $\mathrm{KCH} \mathrm{J2.6,} \mathrm{which} \mathrm{have} \mathrm{been} \mathrm{known}$ for their extensive enzymatic system and ability to perform glycosylation of flavonoids. As a result, five new glycosylated dihydrochalcones were obtained. Biotransformation of 2'-hydroxy-2methylchalcone by B. bassiana $\mathrm{KCH} J 1.5$ resulted in four glycosylated dihydrochalcones: $2^{\prime}$-hydroxy-2methyldihydrochalcone $3^{\prime}$-O- $\beta$-D-( $4^{\prime \prime}$-O-methyl)-glucopyranoside, $2^{\prime}$,3-dihydroxy-2-methyldihydro chalcone $3^{\prime}$-O- $\beta$-D-( $4^{\prime \prime}$-O-methyl)-glucopyranoside, $2^{\prime}$-hydroxy-2-hydroxymethyldihydrochalcone $3^{\prime}$-O- $\beta$-D-(4' $-O$-methyl)-glucopyranoside, and $2^{\prime}, 4$-dihydroxy-2-methyldihydrochalcone $3^{\prime}$-O- $\beta$-D$\left(4^{\prime \prime}-\mathrm{O}\right.$-methyl)-glucopyranoside. In the culture of $\mathrm{I}$. fumosorosea $\mathrm{KCH} \mathrm{J} 2$ only one product was formed-3-hydroxy-2-methyldihydrochalcone 2'-O- $\beta$-D-( $4^{\prime \prime}$-O-methyl)-glucopyranoside. Biotransformation performed by I. farinosa $\mathrm{KCH} \mathrm{J} 2.6$ resulted in the formation of two products: $2^{\prime}$-hydroxy-2methyldihydrochalcone $3^{\prime}-\mathrm{O}-\beta$-D-( $4^{\prime \prime}$-O-methyl)-glucopyranoside and $2^{\prime}, 3$-dihydroxy-2-methyldi hydrochalcone $3^{\prime}-\mathrm{O}-\beta-\mathrm{D}-\left(4^{\prime \prime}-\mathrm{O}\right.$-methyl)-glucopyranoside. The structures of all obtained products were established based on the NMR spectroscopy. All products mentioned above may be used in further studies as potentially bioactive compounds with improved stability and bioavailability. These compounds can be considered as flavor enhancers and potential sweeteners.
\end{abstract}

Keywords: flavonoids; biotransformations; glycosylation; methylchalcone; O-methylglucosides; Beauveria bassiana; Isaria fumosorosea; Isaria farinosa

\section{Introduction}

The widespread and well-documented evidence of health-promoting properties of dietary flavonoids results in a significant increase of interest in their application as dietary supplements and medicaments [1-3].

Chalcones are one of the subclasses of dietary flavonoids, which consist of two aromatic rings joined by a three-carbon $\alpha, \beta$-unsaturated carbonyl system. Their mostly described biological activities can be highlighted as antifungal, antivirus, anti-diabetic, anti-inflammatory, and antitumor [1,4-6].

The poor aqueous solubility of flavonoid aglycones limits their oral bioavailability and, as a consequence, pharmacological application. To overcome this obstacle, many attempts have been made, such as shifting the site of the absorption from the large intestine to the small intestine, increasing metabolic stability and aqueous solubility, inventing novel formulations for topical delivery $[7,8]$. 
Undoubtedly flavonoid core structure and the attached functional groups affect its bioactivity and bioavailability [2]. Flavonoids with methyl moiety have improved metabolic stability, intestinal absorption and bioavailability $[9,10]$.

Modulated physiochemical and biological properties can also be observed for glycosylated flavonoids, which exhibit improved aqueous solubility and intestinal absorption, higher plasma levels, and longer mean residence time in the blood than analogous aglycones. Flavonoid glycosides act as pro-drugs. The sugar unit increases the bioavailability and improves the delivery efficiency, while the flavonoid aglycone acts as the active substance. However, the impact of the glycosylation has not been sufficiently investigated and probably depends on the position of the sugar moiety attached [8,11-14]. Despite numerous in vitro studies concerning the biological activity of flavonoids and their glycosides, the effect on glycosylation in vitro may differ from that observed in vivo. In studies with oral flavonoid administration, glycosides showed similar or even higher anti-inflammatory, anti-diabetic, and antiallergic activity than analogous aglycones [13].

Among flavonoid subclasses, worth attention are dihydrochalcones known for their antimicrobial activity and sweet taste. Presently they are increasingly applied as a healthy alternative for traditional sweeteners in the food industry [15]. The best-known compound is neohesperidin dihydrochalcone, which is about 1500 times sweeter than sucrose and is obtained from immature citrus fruits [16]. Another widely used dietary sweetener, naringin dihydrochalcone, shows anti-oxidant activity and have been reported as a potential therapeutic agent for Alzheimer's Disease, based on its positive effects on the cognitive function of transgenic Alzheimer's Disease mice [17].

From natural sources, dihydrochalcones are isolated as aglycones and their glycosides.Most extensively described dihydrochalcones are phloretin and its 2'-O-glucoside named phloridzin, isolated from a genus of small trees and shrubs Malus. Many studies proved numerous biological activities of phloridzin, such as anti-diabetic, anti-inflammatory, anti-oxidant, antihyperglycemic, antimicrobial, cardio- and hepatoprotective, anti-obesity and others [18-22]. Similar activities have been reported for phloretin [23]. Structureantioxidant capacity relationship studies of dihydrochalcone compounds in Malus proved the antioxidant activity of these compounds through various mechanisms. The presence of the hydroxyl moiety at C-2' increased antioxidant potency of examined dihydrochalcones $[24,25]$.

Others recently isolated from plants dihydrochalcones are, inter alia, phloretin 4O- $\beta$-D-glucopyranoside from the stems Homalium stenophyllum [26], fragnanone $\mathrm{C}$ from Anneslea fragrans twigs [27], 2', 5' -dimethyl-3'-methoxy-4', $6^{\prime}$-dihydroxyl-dihydrochalcone from Empetrum nigrum L. var. japonicum K. Koch (E. nigrum) [28], and glucoside derivatives of phloretin, with attached one or more glucosyl moieties at different positions of flavonoid core, from subaerial parts of Thonningia sanguinea. The latter were tested for their in vitro inhibitory activities against protein tyrosine phosphatase- $1 \mathrm{~B}$, which increased activity is related to obesity, type 2 diabetes and carcinoma [29]. Another compound, $3^{\prime}$-formyl-2', $4^{\prime}, 6^{\prime}$-trihydroxy-5'-methyldihydrochalcone, exhibited antimicrobial, and anticancer potential [30].

Variously substituted chalcone aglycones and glycosides can be obtained by combined chemical and biotechnological methods with entomopathogenic filamentous fungi as biocatalysts [12,31-39] and concerned as new, potentially biologically active compounds with increased bioavailability.

The present study is a continuation of our previous research studies with 2'-hydroxy5 '-methylchalcone, 6-methylflavanone and 6-methylflavone as the biotransformation substrates $[33,34]$. In this study, we synthesized flavonoid compound with the methyl group at $\mathrm{C}-2$ of the chalcone skeleton. Subsequently, we biotransformed the resulting compound using entomopathogenic filamentous fungi strains B. bassiana $\mathrm{KCH} J 1.5$, I. fumosorosea $\mathrm{KCH}$ $\mathrm{J} 2$ and I. farinosa $\mathrm{KCH} \mathrm{J} 2.6$ as biocatalysts.

As a result of biotransformation of 2'-hydroxy-2-methylchalcone in B. bassiana $\mathrm{KCH}$ J1.5 culture we obtained four glycosylated dihydrochalcones. In the case of I. fumosorosea 
$\mathrm{KCH} \mathrm{J2}$ as a biocatalyst only one glycosylation product was obtained. I. farinosa $\mathrm{KCH} \mathrm{J} 2.6$ biotransformed 2'-hydroxy-2-methylchalcone into two products formed also by B. bassiana $\mathrm{KCH} \mathrm{J1.5.}$

According to our best knowledge, all obtained biotransformation products have not been previously known and can be used in biological activity and bioavailability assessment. Moreover, obtained dihydrochalcone glycosides may be concerned as potential flavor enhancers and health-promoting sweeteners.

\section{Results}

2'-Hydroxy-2-methylchalcone was utilized in microbial transformations performed by three entomopathogenic filamentous fungi strains B. bassiana $\mathrm{KCH} \mathrm{J1.5,} \mathrm{I.} \mathrm{fumosorosea}$ $\mathrm{KCH} \mathrm{J2}$, and I. farinosa $\mathrm{KCH}$ J2.6. Microorganisms were isolated from the environment and had been effective in the glycosylation of flavonoids and steroids in our earlier studies $[33,34,40,41]$.

Experiments were performed on a semi-preparative scale to determine the chemical structures of biotransformation products and their isolated yields.

As a result of 2'-hydroxy-2-methylchalcone biotransformation in the B. bassiana $\mathrm{KCH}$ J1.5 culture four glycosylated dihydrochalcones were obtained. In the case of I. fumosorosea $\mathrm{KCH} \mathrm{J2} \mathrm{as} \mathrm{a} \mathrm{biocatalyst,} \mathrm{only} \mathrm{one} \mathrm{product} \mathrm{was} \mathrm{obtained.} \mathrm{The} \mathrm{biotransformation} \mathrm{in} \mathrm{the}$ culture of I. farinosa $\mathrm{KCH} \mathrm{J2.6} \mathrm{resulted} \mathrm{in} \mathrm{the} \mathrm{formation} \mathrm{of} \mathrm{two} \mathrm{products} \mathrm{formed} \mathrm{also} \mathrm{in}$ B. bassiana $\mathrm{KCH}$ J1.5 culture. In the experiment, 2'-hydroxy-2-methylchalcone (3) was synthesized in the Claisen-Schmidt condensation reaction (Scheme 1) (Section 4.1).<smiles>CC(=O)c1ccccc1O</smiles>

1<smiles>Cc1ccccc1C=O</smiles>

2

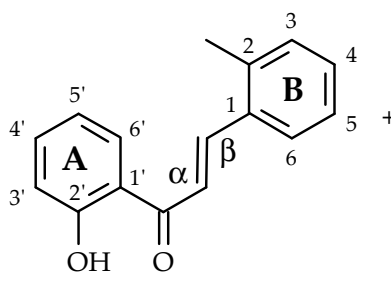

3

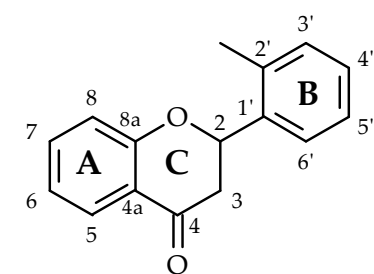

4

Scheme 1. Synthesis of 2'-hydroxy-2-methylchalcone (3) in the Claisen-Schmidt condensation reaction.

The structure of product (3) was confirmed based on NMR (Nuclear Magnetic Resonance)spectroscopy (Tables 1 and 2). In the ${ }^{1} \mathrm{H}$ NMR (Proton Nuclear Magnetic Resonance) spectrum were observed two characteristic signals: the first one from the hydroxyl moiety at $\delta=12.88 \mathrm{ppm}$ with the corresponding signal from C- $2^{\prime}$ in the ${ }^{13} \mathrm{C}$ NMR (Carbon-13 Nuclear Magnetic Resonance) spectrum at $\delta=164.5 \mathrm{ppm}$, and the second one from the three protons of the methyl moiety at $\delta=2.51 \mathrm{ppm}$ with the corresponding signal from $\mathrm{C}-2-\mathrm{CH}_{3}$ in the ${ }^{13} \mathrm{C}$ NMR spectrum at $\delta=19.8 \mathrm{ppm}$ (Supplementary Materials: Figures S2 and S4). In the ${ }^{1} \mathrm{H}$ NMR spectrum were also observed two doublets from protons $\alpha$ and $\beta(\delta=8.25 \mathrm{ppm}$ and $7.94 \mathrm{ppm}$, respectively) and the signals from protons of the A and B rings (Supplementary Materials: Figure S3). In the ${ }^{13} \mathrm{C}$ NMR spectrum was also observed the signal from the carbonyl group at $\delta=195.0 \mathrm{ppm}$ (Supplementary Materials: Figure S4). The couplings between the three protons of the methyl moiety $(\delta=2.51 \mathrm{ppm})$ and the signals from carbons C-1 $(\delta=134.4 \mathrm{ppm}), \mathrm{C}-2(\delta=139.5 \mathrm{ppm})$, and C-3 $(\delta=131.8 \mathrm{ppm})$ confirm substitution with the methyl moiety at position C-2 (Supplementary Materials: Figure S180). Moreover, the protons at $C-6^{\prime}(\delta=8.28 \mathrm{ppm})$ and at $C-4^{\prime}(\delta=7.58 \mathrm{ppm})$ correlate with the signal from carbon at $\mathrm{C}-2^{\prime}(\delta=164.5 \mathrm{ppm})$ confirming substitution with the hydroxyl group at position C-2' (Supplementary Materials: Figure S17). 
Table 1. ${ }^{1} \mathrm{H}-\mathrm{NMR}$ chemical shifts $\delta$ (ppm) and coupling constants $J(\mathrm{~Hz})$ of $2^{\prime}$-hydroxy-2methylchalcone (3) and products of its biotransformation 3a-3e in Acetone-d6, $600 \mathrm{MHz}$ (Supplementary Materials: Figures S2, S20, S38, S57, S75 and S94).

\begin{tabular}{|c|c|c|c|c|c|c|}
\hline \multirow{2}{*}{ Proton } & \multicolumn{6}{|c|}{ Compound } \\
\hline & 3 & $3 a$ & $3 b$ & $3 c$ & $3 d$ & $3 e$ \\
\hline$H-\alpha$ & $\begin{array}{l}7.94(\mathrm{~d}) \\
J=15.3\end{array}$ & $3.40(\mathrm{~m})$ & $3.36(\mathrm{~m})$ & $3.46(\mathrm{~m})$ & $3.33(\mathrm{~m})$ & $3.34(\mathrm{~m})$ \\
\hline $\mathrm{H}-\beta$ & $\begin{array}{l}8.25(\mathrm{~d}) \\
J=15.4\end{array}$ & $3.03(\mathrm{~m})$ & $3.02(\mathrm{~m})$ & $3.10(\mathrm{~m})$ & $2.94(\mathrm{~m})$ & $2.95(\mathrm{~m})$ \\
\hline $\mathrm{H}-3$ & $7.30(\mathrm{~m})$ & $\begin{array}{c}7.15(\mathrm{dd}) \\
J=6.8 \\
J=1.7\end{array}$ & - & $7.40(\mathrm{~m})$ & $\begin{array}{l}6.65(\mathrm{~d}) \\
J=2.5\end{array}$ & - \\
\hline $\mathrm{H}-4$ & $7.36(\mathrm{~m})$ & $7.10(\mathrm{~m})$ & $6.72(\mathrm{~m})$ & $7.20(\mathrm{~m})$ & - & $\begin{array}{l}6.68(\mathrm{~d}) \\
J=8.0\end{array}$ \\
\hline H-5 & $7.30(\mathrm{~m})$ & $7.10(\mathrm{~m})$ & $\begin{array}{l}6.92(\mathrm{t}) \\
J=7.8\end{array}$ & $7.20(\mathrm{~m})$ & $\begin{array}{c}6.59(\mathrm{dd}) \\
J=8.2 \\
J=2.6\end{array}$ & $\begin{array}{l}6.90(\mathrm{t}) \\
J=7.8\end{array}$ \\
\hline H-6 & $\begin{array}{c}7.97(\mathrm{~d}) \\
J=7.8\end{array}$ & $7.23(\mathrm{~m})$ & $6.72(\mathrm{~m})$ & $7.28(\mathrm{~m})$ & $\begin{array}{c}7.03(\mathrm{~d}) \\
J=8.2\end{array}$ & $\begin{array}{c}6.71(\mathrm{~d}) \\
J=7.5\end{array}$ \\
\hline $\mathrm{H}-3^{\prime}$ & $7.01(\mathrm{~m})$ & - & - & - & - & $\begin{array}{c}7.30(\mathrm{dd}) \\
J=8.4 \\
J=0.5\end{array}$ \\
\hline $\mathrm{H}-4^{\prime}$ & $7.58(\mathrm{~m})$ & $\begin{array}{c}7.40(\mathrm{dd}) \\
J=8.0 \\
J=1.2\end{array}$ & $\begin{array}{c}7.40(\mathrm{dd}) \\
J=8.0 \\
J=1.1\end{array}$ & $7.40(\mathrm{~m})$ & $\begin{array}{c}7.39(\mathrm{dd}) \\
J=8.0 \\
J=1.3\end{array}$ & $\begin{array}{c}7.47 \text { (ddd) } \\
J=8.5 \\
J=7.3 \\
J=1.8\end{array}$ \\
\hline $\mathrm{H}-5^{\prime}$ & $7.01(\mathrm{~m})$ & $\begin{array}{l}6.86(\mathrm{t}) \\
J=8.1\end{array}$ & $\begin{array}{l}6.86(\mathrm{t}) \\
J=8.1\end{array}$ & $\begin{array}{l}6.85(\mathrm{t}) \\
J=8.1\end{array}$ & $\begin{array}{l}6.85(\mathrm{t}) \\
J=81\end{array}$ & $\begin{array}{c}7.11(\mathrm{td}) \\
J=7.6 \\
J=0.9\end{array}$ \\
\hline $\mathrm{H}-6^{\prime}$ & $\begin{array}{c}8.28(\mathrm{dd}) \\
J=8.4 \\
J=1.1\end{array}$ & $\begin{array}{c}7.65(\mathrm{dd}) \\
J=8.1 \\
J=1.3\end{array}$ & $\begin{array}{c}7.65(\mathrm{dd}) \\
J=8.2 \\
J=1.4\end{array}$ & $\begin{array}{c}7.65(\mathrm{dd}) \\
J=8.2 \\
J=1.3\end{array}$ & $\begin{array}{c}7.64(\mathrm{dd}) \\
J=8.1 \\
J=1.4\end{array}$ & $\begin{array}{c}7.58(\mathrm{dd}) \\
J=7.7 \\
J=1.8\end{array}$ \\
\hline $\mathrm{H}-\mathrm{-}^{\prime \prime}$ & - & $\begin{array}{c}4.91(\mathrm{~d}) \\
J=7.8\end{array}$ & $\begin{array}{c}4.91(\mathrm{~d}) \\
J=7.8\end{array}$ & $\begin{array}{c}4.91(\mathrm{~d}) \\
J=7.8\end{array}$ & $\begin{array}{c}4.91(\mathrm{~d}) \\
J=7.8\end{array}$ & $\begin{array}{c}5.04(\mathrm{~d}) \\
J=7.8\end{array}$ \\
\hline $\mathrm{H}-2^{\prime \prime}$ & - & $3.50(\mathrm{~m})$ & $\begin{array}{c}3.50 \text { (ddd) } \\
J=9.1 \\
J=7.9 \\
J=3.8\end{array}$ & $3.49(\mathrm{~m})$ & $3.50(\mathrm{~m})$ & $3.53(\mathrm{~m})$ \\
\hline $\mathrm{H}-3^{\prime \prime}$ & - & $\begin{array}{c}3.62(\mathrm{td}) \\
J=9.1 \\
J=3.8\end{array}$ & $\begin{array}{c}3.62(\mathrm{td}) \\
J=9.0 \\
J=3.9\end{array}$ & $3.62(\mathrm{~m})$ & $\begin{array}{c}3.62(\mathrm{td}) \\
J=9.0 \\
J=3.9\end{array}$ & $\begin{array}{c}3.63(\mathrm{td}) \\
J=9.0 \\
J=4.3\end{array}$ \\
\hline $\mathrm{H}-4^{\prime \prime}$ & - & $3.22(\mathrm{~m})$ & $3.22(\mathrm{~m})$ & $3.22(\mathrm{~m})$ & $3.22(\mathrm{~m})$ & $3.20(\mathrm{~m})$ \\
\hline $\mathrm{H}-5^{\prime \prime}$ & - & $\begin{array}{c}3.44 \text { (ddd) } \\
J=9.7 \\
J=4.8 \\
J=2.1\end{array}$ & $\begin{array}{c}3.44 \text { (ddd) } \\
J=9.7 \\
J=4.8 \\
J=2.2\end{array}$ & $3.43(\mathrm{~m})$ & $\begin{array}{c}3.44 \text { (ddd) } \\
J=9.6 \\
J=4.7 \\
J=2.1\end{array}$ & $\begin{array}{c}3.49 \text { (ddd) } \\
J=9.7 \\
J=4.6 \\
J=2.0\end{array}$ \\
\hline
\end{tabular}


Table 1. Cont.

\begin{tabular}{|c|c|c|c|c|c|c|}
\hline \multirow{2}{*}{ Proton } & \multirow[b]{2}{*}{3} & \multicolumn{5}{|c|}{ Compound } \\
\hline & & $3 a$ & $3 b$ & $3 c$ & $3 d$ & $3 e$ \\
\hline $\mathrm{H}-6^{\prime \prime}$ & - & $\begin{array}{c}3.81(\text { ddd }) \\
J=11.6 \\
J=5.1 \\
J=2.0 \\
3.68(\text { ddd }) \\
J=11.6 \\
J=6.9 \\
J=4.9\end{array}$ & $\begin{array}{c}3.82(\mathrm{ddd}) \\
J=11.5 \\
J=5.1 \\
J=2.1 \\
3.68(\mathrm{ddd}) \\
J=11.6 \\
J=6.8 \\
J=4.9\end{array}$ & $\begin{array}{c}3.81 \text { (ddd) } \\
J=11.6 \\
J=5.2 \\
J=2.2 \\
3.68(\mathrm{ddd}) \\
J=11.8 \\
J=7.3 \\
J=4.8\end{array}$ & $\begin{array}{c}3.81 \text { (ddd) } \\
J=11.6 \\
J=5.2 \\
J=2.1 \\
3.68 \text { (ddd) } \\
J=11.7 \\
J=7.0 \\
J=4.8\end{array}$ & $\begin{array}{c}3.83(\text { ddd }) \\
J=7.3 \\
J=4.7 \\
J=2.2 \\
3.68(\mathrm{~m})\end{array}$ \\
\hline $\mathrm{C}^{\prime \prime}-\mathrm{OCH}_{3}$ & - & $3.56(\mathrm{~s})$ & $3.56(\mathrm{~s})$ & $3.56(\mathrm{~s})$ & $3.56(\mathrm{~s})$ & 3.55 (s) \\
\hline $\mathrm{C} 2^{\prime}-\mathrm{OH}$ & $12.88(\mathrm{~s})$ & $12.14(\mathrm{~s})$ & $12.18(\mathrm{~s})$ & $12.17(\mathrm{~s})$ & $12.20(\mathrm{~s})$ & - \\
\hline $\mathrm{C} 3-\mathrm{OH}$ & - & - & $8.16(\mathrm{~s})$ & - & - & $8.08(\mathrm{~s})$ \\
\hline $\mathrm{C} 4-\mathrm{OH}$ & - & - & - & - & $8.02(\mathrm{~s})$ & - \\
\hline $\mathrm{C} 2-\mathrm{CH}_{3}$ & $2.51(\mathrm{~s})$ & $2.35(\mathrm{~s})$ & $2.21(\mathrm{~s})$ & - & $2.27(\mathrm{~s})$ & $2.19(\mathrm{~s})$ \\
\hline $2^{\prime \prime}-\mathrm{O} \underline{\mathrm{H}}$ & - & $\begin{array}{c}4.68(\mathrm{~d}) \\
J=3.5\end{array}$ & $\begin{array}{c}4.68(\mathrm{~d}) \\
J=3.9\end{array}$ & $\begin{array}{c}4.59(\mathrm{~d}) \\
J=3.9\end{array}$ & $\begin{array}{c}4.63(\mathrm{~d}) \\
J=3.7\end{array}$ & $\begin{array}{c}4.65(\mathrm{~d}) \\
J=4.1\end{array}$ \\
\hline $3^{\prime \prime}-\mathrm{OH}$ & - & $\begin{array}{c}4.42(\mathrm{~d}) \\
J=3.9\end{array}$ & $\begin{array}{c}4.41(\mathrm{~d}) \\
J=4.0\end{array}$ & $\begin{array}{c}4.39(\mathrm{~d}) \\
J=4.0\end{array}$ & $\begin{array}{c}4.40(\mathrm{~d}) \\
J=4.0\end{array}$ & $\begin{array}{c}4.48(\mathrm{~d}) \\
J=4.3\end{array}$ \\
\hline $6^{\prime \prime}-\mathrm{OH}$ & - & $\begin{array}{c}3.76(\mathrm{dd}) \\
J=11.7 \\
J=4.8\end{array}$ & $3.76(\mathrm{~m})$ & $\begin{array}{c}3.74(\mathrm{dd}) \\
J=11.1 \\
J=5.9\end{array}$ & $\begin{array}{c}3.75(\mathrm{dd}) \\
J=12.8 \\
J=5.8\end{array}$ & $\begin{array}{c}3.71(\mathrm{dd}) \\
J=9.3 \\
J=4.5\end{array}$ \\
\hline $2-\mathrm{CH}_{2}^{-}$ & - & - & - & $\begin{array}{c}4.73(\mathrm{~d}) \\
J=5.5\end{array}$ & - & - \\
\hline $2-\mathrm{CH}_{2}-\mathrm{OH}$ & - & - & - & $\begin{array}{l}4.15(\mathrm{t}) \\
J=5.4\end{array}$ & - & - \\
\hline
\end{tabular}

2.1. Biotransformation of 2'-Hydroxy-2-methylchalcone (3) in the Culture of B.bassiana KCH J1.5

As a result of 9-day biotransformation of 2'-hydroxy-2-methylchalcone in the culture of B. bassiana $\mathrm{KCH} \mathrm{J1.5} \mathrm{four} \mathrm{products} \mathrm{were} \mathrm{obtained:} \mathrm{2'-hydroxy-2-methyldihydrochalcone}$ $3^{\prime}$-O- $\beta$-D-( $4^{\prime \prime}-O$-methyl)-glucopyranoside (3a) with a $2.9 \%$ yield $(2.6 \mathrm{mg}), 2^{\prime}, 3$-dihydroxy-2methyldihydrochalcone $3^{\prime}-\mathrm{O}-\beta$-D-( $4^{\prime \prime}$-O-methyl)-glucopyranoside (3b) with a $13.1 \%$ yield (12.3 mg), $2^{\prime}$-hydroxy-2-hydroxymethyldihydrochalcone $3^{\prime}$-O- $\beta$-D-( $4^{\prime \prime}$-O-methyl)-glucopy ranoside (3c) with a $4.8 \%$ yield $(4.5 \mathrm{mg})$, and $2^{\prime}, 4$-dihydroxy-2-methyldihydrochalcone $3^{\prime}$-O- $\beta$-D-( $4^{\prime \prime}$-O-methyl)-glucopyranoside (3d) with a $5.0 \%$ yield $(4.7 \mathrm{mg}$ ) (Scheme 2$)$. Biotransformation products were isolated and purified utilizing the preparative Thin Layer Chromatography (TLC) method with a mixture of chloroform and methanol $(9: 1 \mathrm{v} / \mathrm{v})$ as eluent.

Table 2. ${ }^{13} \mathrm{C}-\mathrm{NMR}$ chemical shifts $\delta(\mathrm{ppm})$ and coupling constants $J(\mathrm{~Hz})$ of $2^{\prime}$-hydroxy-2methylchalcone (3) and products of its biotransformation 3a-3e in Acetone-d6, $151 \mathrm{MHz}$ (Supplementary Materials Figures S4, S23, S41, S60, S78 and S97).

\begin{tabular}{ccccccc}
\hline \multirow{2}{*}{ Carbon } & \multicolumn{7}{c}{ Compound } \\
\cline { 2 - 7 } & $\mathbf{3}$ & $\mathbf{3 a}$ & $\mathbf{3 b}$ & $\mathbf{3 c}$ & $\mathbf{3 d}$ & $\mathbf{3 e}$ \\
\hline C- $\alpha$ & 122.3 & 40.2 & 40.5 & 41.3 & 40.6 & 44.7 \\
C- $\beta$ & 143.4 & 28.0 & 28.5 & 27.3 & 27.4 & 28.6 \\
C-1 & 134.4 & 140.1 & 141.5 & 140.0 & 130.7 & 142.1 \\
C-2 & 139.5 & 136.8 & 123.2 & 140.7 & 137.9 & 123.2 \\
C-3 & 131.8 & 131.0 & 156.3 & 129.1 & 117.9 & 156.1 \\
C-4 & 131.6 & 127.1 & 113.7 & 127.0 & 156.6 & 113.4 \\
\hline
\end{tabular}


Table 2. Cont.

\begin{tabular}{ccccccc}
\hline \multirow{2}{*}{ Carbon } & \multicolumn{6}{c}{ Compound } \\
\cline { 2 - 7 } & $\mathbf{3}$ & $\mathbf{3 a}$ & $\mathbf{3 b}$ & $\mathbf{3 c}$ & $\mathbf{3 d}$ & 3e \\
\hline $\mathrm{C}-5$ & 127.3 & 126.9 & 126.9 & 128.2 & 113.7 & 126.8 \\
$\mathrm{C}-6$ & 127.8 & 129.6 & 121.1 & 130.0 & 130.6 & 121.0 \\
$\mathrm{C}-1^{\prime}$ & 120.9 & 121.5 & 121.5 & 121.5 & 121.5 & 131.0 \\
$\mathrm{C}-2^{\prime}$ & 164.5 & 153.5 & 153.6 & 153.7 & 153.6 & 157.1 \\
$\mathrm{C}-3^{\prime}$ & 119.0 & 147.2 & 147.2 & 147.2 & 147.2 & 117.3 \\
$\mathrm{C}-4^{\prime}$ & 137.5 & 123.9 & 123.9 & 124.0 & 123.9 & 133.9 \\
$\mathrm{C}-5^{\prime}$ & 119.9 & 119.3 & 119.3 & 119.3 & 119.3 & 123.1 \\
$\mathrm{C}-6^{\prime}$ & 131.4 & 124.8 & 124.8 & 124.8 & 124.8 & 130.4 \\
$\mathrm{C}-1^{\prime \prime}$ & - & 102.6 & 102.6 & 102.6 & 102.6 & 102.4 \\
$\mathrm{C}-2^{\prime \prime}$ & - & 74.9 & 74.9 & 74.9 & 74.9 & 75.0 \\
$\mathrm{C}-3^{\prime \prime}$ & - & 77.9 & 77.9 & 77.9 & 77.9 & 78.1 \\
$\mathrm{C}-4^{\prime \prime}$ & - & 80.0 & 80.0 & 80.0 & 80.0 & 80.1 \\
$\mathrm{C}-5^{\prime \prime}$ & - & 77.2 & 77.1 & 77.2 & 77.2 & 77.3 \\
$\mathrm{C}-6^{\prime \prime}$ & - & 62.1 & 62.1 & 62.1 & 62.1 & 62.1 \\
$4^{\prime \prime}-\mathrm{OCH}_{3}$ & - & 60.6 & 60.5 & 60.5 & 60.5 & 60.6 \\
$\mathrm{C}=\mathrm{O}$ & 195.0 & 206.8 & 206.9 & 207.0 & 207.2 & 202.6 \\
$2-\mathrm{CH}_{3}$ & 19.8 & 19.4 & 11.4 & - & 19.5 & 11.5 \\
$2-\underline{\mathrm{C}} \mathrm{H}_{2}$ & - & - & - & 62.9 & - & - \\
\hline
\end{tabular}

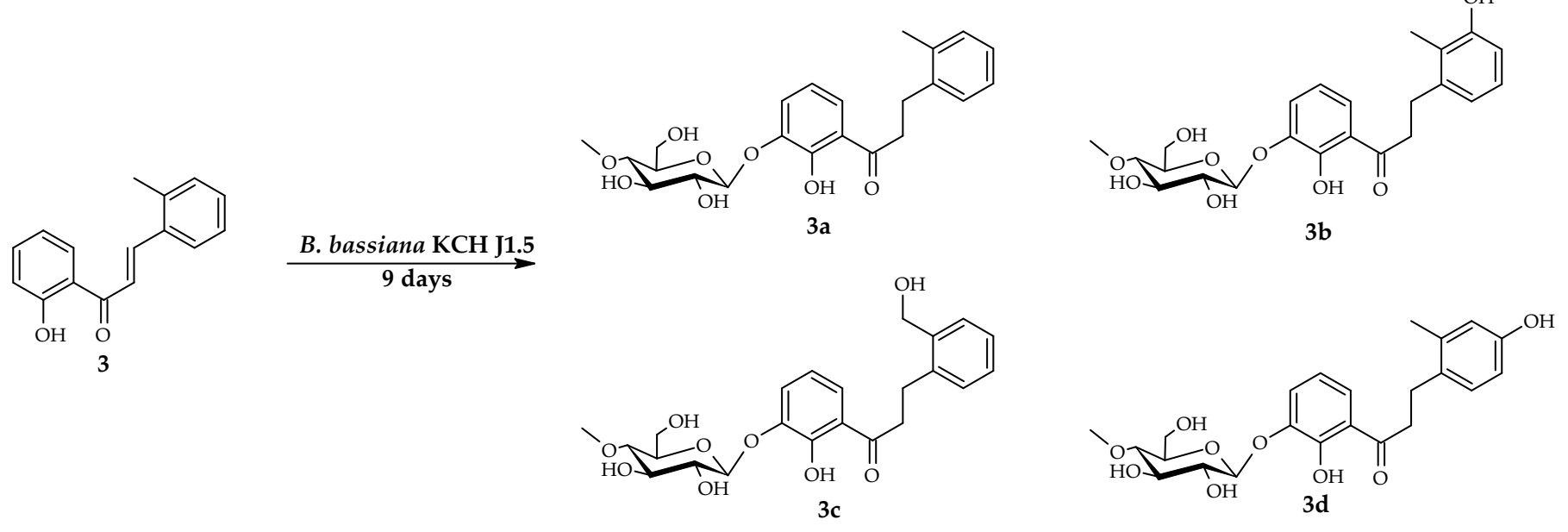

Scheme 2. Microbial transformation of 2'-hydroxy-2-methylchalcone (3) in B. bassiana KCH J1.5 culture.

The structures of products (3a-3d) were determined based on NMR spectroscopy (Tables 1 and 2, Schemes 3-6 showing key COSY (Correlation Spectroscopy) and HMBC (Heteronuclear Multiple Bond Coherence) correlations). In all cases, the presence of a glucoside moiety was confirmed by five characteristic carbon signals observed in the region from $\delta=80.0 \mathrm{ppm}$ to $\delta=62.1 \mathrm{ppm}$ in the ${ }^{13} \mathrm{C}$-NMR spectra (Supplementary Materials: Figures S25, S43, S62 and S80), as well as proton signals of $\delta_{\mathrm{H}}$ ranging from $\delta=3.81 \mathrm{ppm}$ to $\delta=3.22$ ppm in the ${ }^{1} \mathrm{H}-\mathrm{NMR}$ spectra (Supplementary Materials: Figures S22, S40, S59 and S77). The attachment of a glycosidic unit to substrate (3) was also confirmed by a one-proton doublet from proton at the anomeric carbon atom at $\delta=4.91 \mathrm{ppm}$ in the ${ }^{1} \mathrm{H}-\mathrm{NMR}$ spectra. The coupling constant $(J=7.8 \mathrm{~Hz})$ for the anomeric proton was evidence of the glucose $\beta$-configuration. The sugar unit $C-4^{\prime \prime}$ hydroxyl group has been $O$-methylated, because in the ${ }^{1} \mathrm{H}-\mathrm{NMR}$ spectra a three-proton singlet at $\delta=3.56 \mathrm{ppm}$, with the corresponding signal at $\delta=60.5 \mathrm{ppm}$ in the ${ }^{13} \mathrm{C}-\mathrm{NMR}$ spectra was observed. The C- $4^{\prime \prime}$ hydroxyl group methylation was detected based on the HMBC experiment, where the proton signal due to $-\mathrm{OCH}_{3}$ was correlated with the signal of C-4" $(\delta=80.0 \mathrm{ppm})$ in the glucose unit (Supplementary Materials: Figures S35, S54, S72 and S90). In the products 
(3a-3d) also occurred reduction of a double bond between C- $\alpha$ and C- $\beta$. In the ${ }^{1} \mathrm{H}$ NMR spectra the protons at $C-\alpha$ were shifted from $7.94 \mathrm{ppm}(3)$ to $3.40 \mathrm{ppm}(3 \mathbf{a}), 3.36 \mathrm{ppm}(3 \mathbf{b})$, $3.46 \mathrm{ppm}(3 \mathrm{c})$, and $3.33 \mathrm{ppm}(\mathbf{3 d})$. The protons at $C-\beta$ were shifted from $8.25 \mathrm{ppm}$ (3) to $3.03 \mathrm{ppm}$ (3a), $3.02 \mathrm{ppm}$ (3b), $3.10 \mathrm{ppm}$ (3c), and $2.94 \mathrm{ppm}$ (3d). Furthermore, protons at $C-\alpha$ and $C-\beta$ were correlated with the carbonyl group and the proton at $C-\alpha$ was correlated with C-1 in the HMBC spectra (Supplementary Materials: Figures S35, S54, S55, S72, S73, $\mathrm{S} 91$ and S92). The signals from one proton of the hydroxyl group at $\mathrm{C}-2^{\prime}$ in the products (3a-3d) and three protons of the methyl group at C-2 in the products (3a), $(3 \mathbf{b})$ and (3d) remained intact. In products (3a-3d) $4^{\prime \prime}$-O-methyl-glucopyranoside was attached at C- $3^{\prime}$, because in the HMBC spectrum shifted proton at $2^{\prime}$-hydroxyl group $(\delta=12.14 \mathrm{ppm}-$ (3a), $\delta=12.18 \mathrm{ppm}-(3 \mathbf{b}), \delta=12.17 \mathrm{ppm}-(3 \mathbf{c}), \delta=12.20 \mathrm{ppm}-(3 \mathbf{d}))$ and the proton at the anomeric carbon atom $(\delta=4.91 \mathrm{ppm}-(\mathbf{3 a}-\mathbf{3 d}))$ were correlated with shifted signal from C-3' $(\delta=147.2$ ppm-(3a-3d)) spectra (Supplementary Materials: Figures S33, S35, S51, S54, S70, S72, S88 and S91). Moreover, the above mentioned hydroxyl group ( $\delta=12.14$ ppm-(3a), $\delta=12.18 \mathrm{ppm}-(3 \mathbf{b}), \delta=12.17 \mathrm{ppm}-(3 \mathbf{c}), \delta=12.20 \mathrm{ppm}-(\mathbf{3 d}))$ couples with the signals from $C-1^{\prime}(\delta=121.5 \mathrm{ppm}-(\mathbf{3 a}-\mathbf{3 d})), C-2^{\prime}(\delta=153.5 \mathrm{ppm}-(\mathbf{3 a}), \delta=153.6 \mathrm{ppm}-$ (3a) and (3d), $\delta=153.7 \mathrm{ppm}-(3 \mathbf{c}))$, and $C-3^{\prime}(\delta=147.2 \mathrm{ppm}-(3 \mathbf{a}-3 \mathbf{d}))$, but not with the signal from $C-4^{\prime}$, indicating that its position is at C-2' (not at C-3') (Supplementary Materials: Figures S33, S51, S70 and S88). The signal from proton at $C-5^{\prime}(\delta=6.86 \mathrm{ppm}-(3 \mathbf{a}-3 \mathbf{b})$, $\delta=6.85 \mathrm{ppm}-(3 \mathrm{c}-3 \mathrm{~d}))$ also correlates with the shifted signal from C-3' $(\delta=147.2 \mathrm{ppm}-$ (3a-3d)), confirming $4^{\prime \prime}-\mathrm{O}$-methylglucosylation occurring at C-3' (Supplementary Materials: Figure S34, S52, S71 and S89).
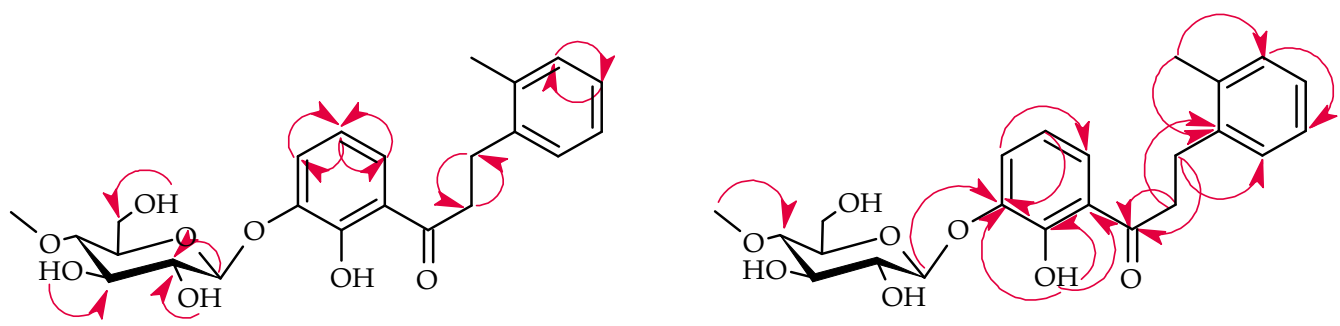

Scheme 3. Key COSY (on the left) and HMBC (on the right) correlations for the structure elucidation of product (3a).
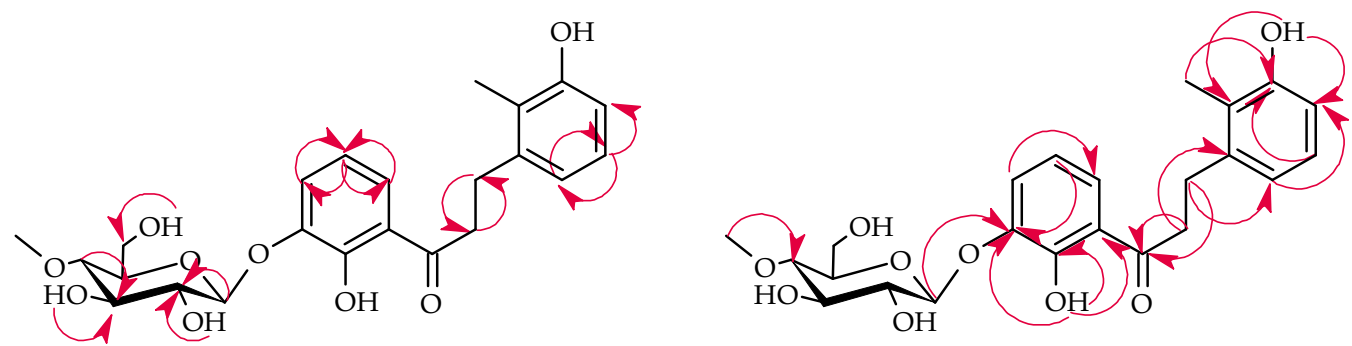

Scheme 4. Key COSY (on the left) and HMBC (on the right) correlations for the structure elucidation of product (3b).
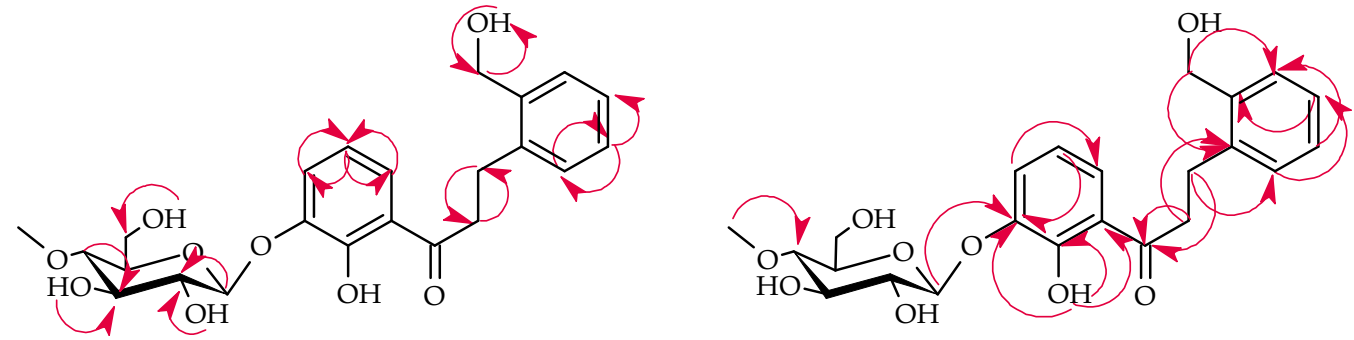

Scheme 5. Key COSY (on the left) and HMBC (on the right) correlations for the structure elucidation of product $(3 \mathrm{c})$. 

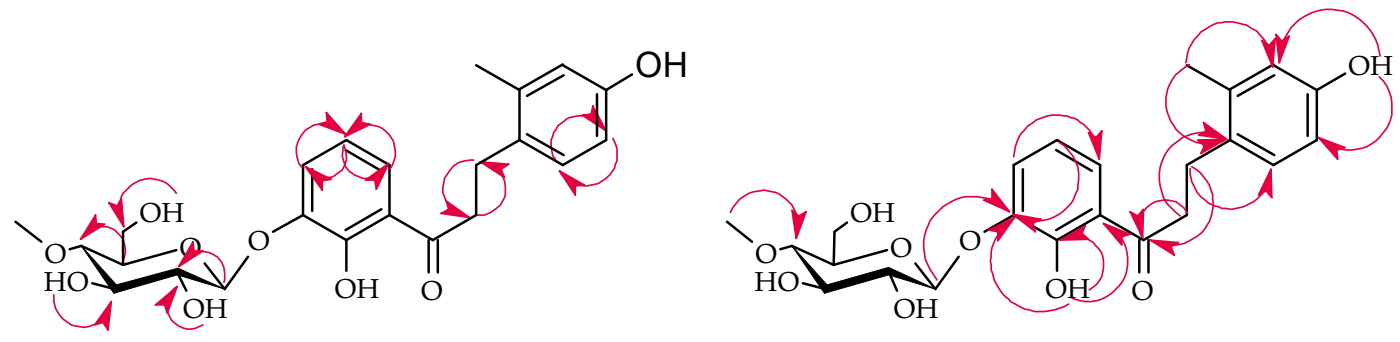

Scheme 6. Key COSY (on the left) and HMBC (on the right) correlations for the structure elucidation of product (3d).

The structure of the product (3a) was established as 2'-hydroxy-2-methyldihydrochal cone 3'-O- $\beta$-D-(4'-O-methyl)-glucopyranoside (Scheme 3).

In the product (3b) (2',3-dihydroxy-2-methyldihydrochalcone $3^{\prime}-\mathrm{O}-\beta$-D-( $4^{\prime \prime}$-O-methyl)glucopyranoside), in the ${ }^{1} \mathrm{H}$ NMR spectrum, the singlet from the proton of the hydroxyl group also appeared $(\delta=8.16 \mathrm{ppm})$ and shifted signals from $\mathrm{B}$ ring were observed: one triplet from the proton at $C-5(\delta=6.92 \mathrm{ppm})$ and one doublet of doublets from the protons at C- 6 and C-4 $(\delta=6.72 \mathrm{ppm})$ indicating that the attachment of an electronegative hydroxyl group occurred at C-3 (Supplementary Materials: Figure S39). Moreover, in the HMBC experiment hydroxyl group at C-3 $(\delta=8.16 \mathrm{ppm})$ was correlated with C-2 signal $(\delta=123.2 \mathrm{ppm})$ and C-3 signal $(\delta=156.3 \mathrm{ppm}$ shifted from $\delta=131.8 \mathrm{ppm}$ in substrate (3)) (Supplementary Materials: Figure S52). The signal from the methyl group at C-2 $(\delta=2.21 \mathrm{ppm})$ was also correlated with shifted C-3 signal (Supplementary Materials: Figure S54) (Scheme 4).

In the case of product (3c) (2'-hydroxy-2-hydroxymethyldihydrochalcone 3'-O- $\beta$-D( $4^{\prime \prime}$-O-methyl)-glucopyranoside), in ${ }^{1} \mathrm{H}$ NMR spectrum shifted signals from $\mathrm{B}$ ring were observed: one signal from the proton at $C-3(\delta=7.40 \mathrm{ppm})$, which merged with the signal from not shifted proton at $C-4^{\prime}$, one multiplet from the proton at $C-6(\delta=7.28 \mathrm{ppm})$, and one merged signal from the protons at C-4 and C-5 $(\delta=7.20 \mathrm{ppm})$ (Supplementary Materials: Figure S58). In the ${ }^{1} \mathrm{H}$ NMR spectrum, two additional signals were observed: one doublet from two protons at the methylene group at $C-2(\delta=4.73 \mathrm{ppm})$ and one triplet from the proton at hydroxyl group attached to this methylene group $(\delta=4.15 \mathrm{ppm})$. In the COSY experiment can be observed coupling between both signals, confirming hydroxylation of the methyl moiety at C-2 (Supplementary Materials: Figure S65). The two protons from the methylene group $(\delta=4.73 \mathrm{ppm})$ was also correlated with $\mathrm{C}-1(\delta=140.0 \mathrm{ppm})$ and C-3 $(\delta=129.1 \mathrm{ppm})$ in the HMBC experiment, also indicating hydroxylation at C2- $\mathrm{CH}_{3}$ (Supplementary Materials: Figure S72) (Scheme 5). Such a reaction was observed previously in the case of the attachment of the hydroxyl moiety to the methyl moiety in the biotransformation of 6-methylflavanone performed also by B. bassiana $\mathrm{KCH} \mathrm{J1} .5$ [34].

In the product (3d), the substitution with the hydroxyl moiety at C-4 was confirmed by the appearance of singlet at $\delta=8.02 \mathrm{ppm}$ in the ${ }^{1} \mathrm{H}$ NMR spectrum and correlation between this signal and signals from carbon C-3 $(\delta=117.9 \mathrm{ppm})$ and C-5 $(\delta=113.7 \mathrm{ppm})$ in the HMBC experiment (Supplementary Materials: Figures S76 and S88) (Scheme 6).

\subsection{Biotransformation of 2'-Hydroxy-2-methylchalcone (3) in the Culture of I. fumosorosea $\mathrm{KCH} \mathrm{J2}$}

I. fumosorosea $\mathrm{KCH} \mathrm{J} 2$ was the only one to biotransform $2^{\prime}$-hydroxy-2-methylchalcone (3) into 3-hydroxy-2-methyldihydrochalcone $2^{\prime}-O-\beta$-D-(4'-O-methyl)-glucopyranoside (3e) The isolated yield of (3e) was 5.3\% (4.8 mg) (Scheme 7). 

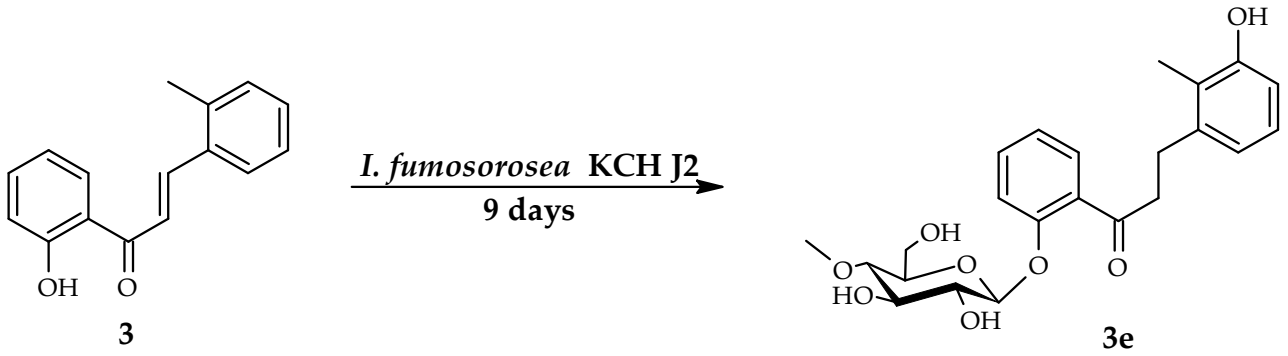

Scheme 7. Microbial transformation of 2'-hydroxy-2-methylchalcone (3) in I. fumosorosea $\mathrm{KCH}$ J2 culture.

The structure of product 3e was established based on the NMR spectroscopy (Tables 1 and 2, Scheme 8 (with key COSY and HMBC correlations). The resulting compound was $4^{\prime \prime}-O$-methylglycosylated dihydrochalcone, like products (3a-3d). However, in this case, glycosylation occurred at C-2. In the ${ }^{1} \mathrm{H}$ NMR spectrum signal from the hydroxyl moiety at $C-2^{\prime}(\delta=12.88 \mathrm{ppm})$ disappeared, indicating substitution at this position. At $\delta=8.08$ ppm appeared singlet from one proton demonstrating substrate hydroxylation at another position (Supplementary Materials: Figure S95). The three-proton signal of the methyl moiety at C-2 was shifted from $\delta=2.51$ ppm to $\delta=2.19$ ppm (like product (3b)) indicating an electronegative atom's attachment in the adjacent position at C-3. Moreover, in the HMBC experiment, the signal from the hydroxyl group at C-3 $(\delta=8.08$ ppm $)$ was coupled with the shifted signal from the carbon at C-3 $(\delta=131.8 \mathrm{ppm}$ in $(3), \delta=156.1 \mathrm{ppm}$ in (3e)) and triplet from one proton at C-5 $(\delta=6.90 \mathrm{ppm})$ was also coupled with the signal from carbon at C-3 (Supplementary Materials: Figure S107). The substitution with the $4^{\prime \prime}-\mathrm{O}$ methylglucosyl moiety at C-2' was confirmed by coupling between the signal from proton at the anomeric carbon atom $(\delta=5.04 \mathrm{ppm})$ and the signal from carbon at C-2', which was shifted from $\delta=164.5 \mathrm{ppm}$ to $\delta=157.1 \mathrm{ppm}$ (Supplementary Materials: Figure S109). The coupling between proton at $6^{\prime}(\delta=7.58 \mathrm{ppm})$, proton at $\mathrm{C}-4^{\prime}(\delta=7.47 \mathrm{ppm})$, proton at C-3' $(\delta=7.30 \mathrm{ppm})$ and carbon at C-2' also confirmed glycosylation at C-2' (Supplementary Materials: Figure S107).
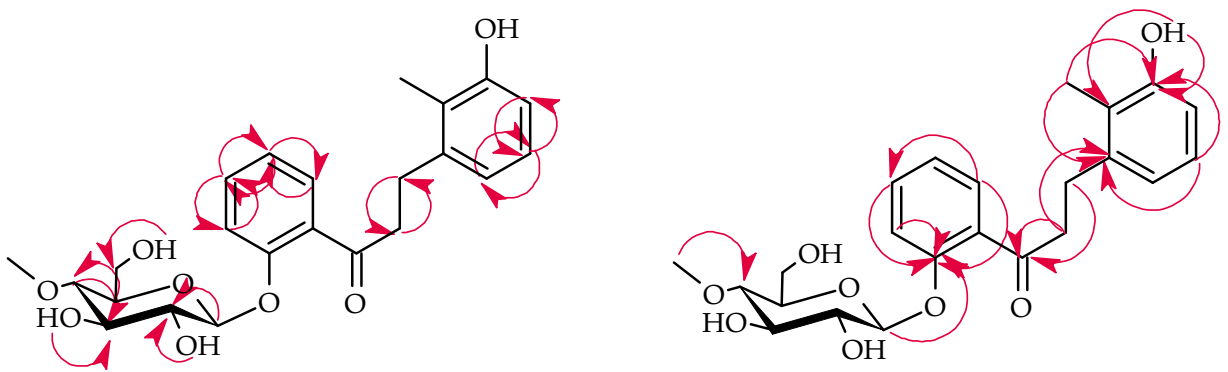

Scheme 8. Key COSY (on the left) and HMBC (on the right) correlations for the structure elucidation of product (3e).

\subsection{Biotransformations of $2^{\prime}$-Hydroxy-2-methylchalcone (3) in the Culture of I. farinosa KCH J2.6}

In the case of biotransformation of 2 -hydroxy-2-methylchalcone (3) performed in $I$. farinosa $\mathrm{KCH} \mathrm{J2.6} \mathrm{culture} \mathrm{two} \mathrm{products} \mathrm{were} \mathrm{obtained} \mathrm{that} \mathrm{were} \mathrm{formed} \mathrm{also} \mathrm{by} \mathrm{B.} \mathrm{bassiana}$ $\mathrm{KCH}$ J1.5 2'-hydroxy-2-methyldihydrochalcone 3'-O- $\beta$-D-(4' -O-methyl)-glucopyranoside (3a) with $7.9 \%$ yield (7.2 mg) and $2^{\prime}, 3$-dihydroxy-2-methyldihydrochalcone $3^{\prime}-\mathrm{O}-\beta$-D- $\left(4^{\prime \prime}\right.$ O-methyl)-glucopyranoside (3b) with $9.6 \%$ yield $(9.0 \mathrm{mg}$ ) (Scheme 9 ). 


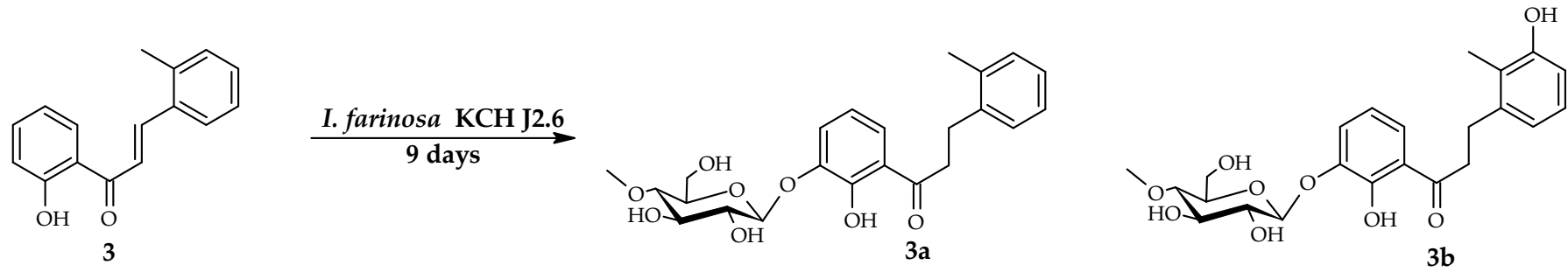

Scheme 9. Microbial transformation of 2'-hydroxy-2-methylchalcone(3) in I. farinosa KCH J2.6 culture.

\section{Discussion}

The previous studies of enzymatic O-glycosylation of chalcones by uridine diphosphate (UDP) glycosyltransferases (UGTs) showed three sites of the attachment of the glucosyl moiety: $2^{\prime}, 4^{\prime}$ and less often 4 [23]. The product obtained in the presented study in the culture of I. fumosorosea $\mathrm{KCH} J 23$-hydroxy-2-methyldihydrochalcone $2^{\prime}-O-\beta$-D- $\left(4^{\prime \prime}-O-\right.$ methyl)-glucopyranoside (3e) corresponds to this pattern. However, microbial glycosylation of chalcones performed by filamentous fungi is rarely reported. Biotransformation of xanthohumol in the cultures of Penicillium chrysogenum 6933 [42], Absidia coerulea AM93 and Rhizopus nigricans UPF701 [43] led to the formation of $4^{\prime}-O-\beta$-D-glucopyranoside derivative and in the cultures of B. bassiana AM278 [44] and B. bassiana AM446 [43] to 4'-O- $\beta$-D-(4'$O$-methyl)-glucopyranoside derivative. In our previous study, we showed results of the glycosylation of 2'-hydroxy-5'-methylchalcone. Both used strains B. bassiana $\mathrm{KCH} \mathrm{J1.5}$ and I. fumosorosea $\mathrm{KCH} \mathrm{J} 2$ were capable of $4^{\prime \prime}$-O-methyl-glycosylation at C-3 [34]. On the other hand, to the best of our knowledge, the attachment of the $4^{\prime \prime}$-O-methyl-glucosyl moiety at $\mathrm{C}^{-3^{\prime}}$ observed in the cultures B. bassiana $\mathrm{KCH} \mathrm{J} 1.5$ and I. farinosa $\mathrm{KCH} \mathrm{J} 2.6$ has not been described in the literature yet and is related to the specific regioselectivity of entomopathogenic filamentous fungi enzymes involved in this reaction.

The attempts have also been made to glycosylate dihydrochalcones. Overwin et al. showed that a non-Leloir glycosyltransferase, amylosucrase from Neisseria polysaccharea, performed the stereospecific glycosylation of phloretin at position C-4' [45].

On the other hand, the reduction of the double bond of chalcones has been described in the literature as the result of biotransformation performed by many microorganisms: bacteria (Stenotrophomonas maltophilia KB2 [46], Rhodococcus sp. DSM 364, Lactobacillus sp. C2 PCM 2851, Rhodotorula rubra AM 82 [5]), cyanobacteria (Spirulina platensis, Anabaena sp., Anabaena laxa, Aphanizomenon klebahnii, Nodularia moravica, Chroococcus minutes, Merismopedia glauca, Synechocystis aquatilis [47], yeast (Yarrowia lipolytica KCH 71, Rhodotorula glutinis $\mathrm{KCH} 242$, Rhodotorula rubra KCH 4, Saccharomyces cerevisiae KCH 464 [15], Y. lipolytica KCH 71 [48], S. cerevisiae - a baker's yeast (BY) from Fleischmann and two industrial yeast strains (CAT-1 and PE-2) [49]), filamentous fungi (Syncephalastrum racemosum $\mathrm{KCH} 105$, Chaetomium sp. KCH 6651, Didymosphaeria igniaria KCH 6670, A. coerulea KCH 93, Fusarium culmorum $\mathrm{KCH}$ 10) [15].

However, to the best of our knowledge, we are the first team to describe biotransformations leading to the reduction of the double bond together with the glycosylation of the chalcone substrate. All three used strains of entomopathogenic filamentous fungi $B$. bassiana $\mathrm{KCH} \mathrm{J} 1.5$, I. fumosorosea $\mathrm{KCH} \mathrm{J2}$, and I. farinosa $\mathrm{KCH} \mathrm{J} 2.6$ were able to carry out such reactions.

\section{Materials and Methods}

\subsection{Substrate}

The biotransformation substrate-2'-hydroxy-2-methylchalcone (3) was obtained by the Claisen-Schmidt condensation reaction between $2^{\prime}$-hydroxyacetophenone (1) and 2methylbenzaldehyde (2) (purchased from Sigma-Aldrich (St. Louis, MO, USA)), showed in Scheme 1. The compounds were dissolved in methanol and the process was carried out under alkaline conditions at high temperature [34,50,51]. 2'-Hydroxy-2-methylchalcone (3) 
was obtained with a $63.8 \%$ yield and was used as the biotransformation substrate. As a result of spontaneous cyclization of 2'-hydroxy-2-methylchalcone (3) 2'-methylflavanone (4) was obtained with $28.2 \%$ yield (Scheme 1 ).

The physical data, including color and form, melting point $\left({ }^{\circ} \mathrm{C}\right)$, molecular ion mass, molecular formula, retention time $t_{\mathrm{R}}(\mathrm{min})$, retardation factor $\mathrm{Rf}$, andNMR spectral data of the resulting compound (3)are presented below, in Tables 1 and 2, and in the Supplementary Materials.

\section{2'-Hydroxy-2-methylchalcone (3)}

Yellow crystals, $\mathrm{mp}=81-82{ }^{\circ} \mathrm{C}$, ESIMS $\mathrm{m} / \mathrm{z} 239.0\left(\left[\mathrm{M}+\mathrm{H}^{+}, \mathrm{C}_{16} \mathrm{H}_{14} \mathrm{O}_{2}\right), \mathrm{t}_{\mathrm{R}}=18.47\right.$, $\mathrm{Rf}=0.95,{ }^{1} \mathrm{H}-\mathrm{NMR}$, see Table $1,{ }^{13} \mathrm{C}-\mathrm{NMR}$, see Table 2, Supplementary Materials: Figures S1-S18.

\subsection{Microorganisms}

The biotransformations were performed using three strains of entomopathogenic filamentous fungi B. bassiana $\mathrm{KCH}$ J1.5, I. fumosorosea $\mathrm{KCH}$ J2, and I. farinosa $\mathrm{KCH}$ J2.6. Microorganisms were assembled from the Department of Chemistry of Wrocław University of Environmental and Life Sciences, Poland.

The description of material collection, fungi propagation, and genetic identification have already been described in our previous papers $[33,40]$. The filamentous fungi were maintained on potato slants at $4^{\circ} \mathrm{C}$ and were subcultured to a liquid medium before use in the experiments $[33,40]$.

\subsection{Analysis}

The course of the biotransformation was tracked by chromatographic methods (TLC, HPLC). TLC analysis was carried out using TLC Silica gel 60/Kieselguhr F254 (0.2 mm thick) plates (Merck, Darmstadt, Germany). As the developing system was used a mixture of chloroform (Chempur, Piekary Śląskie, Poland) and methanol (Chempur, Piekary Ślaskie, Poland) $(9: 1 v / v)$. The products were observed under the ultraviolet lamp at $\lambda=254 \mathrm{~nm}$ and $\lambda=365 \mathrm{~nm}$ without additional visualization.

HPLC analyses were performed on a Dionex Ultimate 3000 instrument (Thermo Fisher Scientific, Waltham, MA, USA) with a DAD-3000 diode array detector using analytical octadecyl silica (ODS) 2 column (4.6 mm $\times 250 \mathrm{~mm}$, Waters, Milford, MA, USA) and pre-column. The gradient program was as follows: initial conditions- $32.5 \% \mathrm{~B}$ in $\mathrm{A}, 4 \mathrm{~min}-$ $40 \% \mathrm{~B}$ in $\mathrm{A}, 8 \mathrm{~min}-40 \% \mathrm{~B}$ in $\mathrm{A}, 10 \mathrm{~min}-45 \% \mathrm{~B}$ in $\mathrm{A}, 15 \mathrm{~min}-95 \% \mathrm{~B}$ in $\mathrm{A}, 18 \mathrm{~min}-95 \%$ $\mathrm{B}$ in $\mathrm{A}, 19 \mathrm{~min}-32.5 \% \mathrm{~B}$ in $\mathrm{A}, 23 \mathrm{~min}-32.5 \% \mathrm{~B}$ in $\mathrm{A}$. The flow rate was $1 \mathrm{~mL} \mathrm{~min}^{-1}$, the injection volume was $5 \mu \mathrm{L}$, and the detection wavelength was $280 \mathrm{~nm}$ [34].

Separation of the products obtained by the scale-up biotransformation was achieved using 500 and $1000 \mu \mathrm{M}$ preparative TLC silica gel plates (Analtech, Gehrden, Germany). The elution of the post-reaction products from the adsorbent on TLC plate was performed with the use of mixture of chloroform and methanol $(9: 1 \mathrm{v} / \mathrm{v})$. Afterward, separate gel fractions were extracted with $20 \mathrm{~mL}$ of ethyl acetate (Chempur, Piekary Ślaskie, Poland) three times. The extracts from a single fraction were combined. The solvent was evaporated from all fractions under reduced pressure and $0.9 \mathrm{~cm}^{3}$ of deuterated acetone was added to each sample prior to the NMR analysis [34].

NMR analyses $\left({ }^{1} \mathrm{H}-\mathrm{NMR},{ }^{13} \mathrm{C}-\mathrm{NMR}\right.$, COSY, Heteronuclear Single Quantum Correlation-HSQC), HMBC) were performed using a DRX Avance ${ }^{\mathrm{TM}} 600 \mathrm{MHz}$ NMR spectrometer (Bruker, Billerica, MA, USA).

Molecular formulas of all products were confirmed by analysis performed on the LCMS 8045 SHIMADZU Triple Quadrupole Liquid Chromatograph Mass Spectrometer with electrospray ionization (ESI) source (Shimadzu, Kyoto, Japan). Identification of compounds was performed as described previously, with minor modifications [41]. Analyses were conducted using method "MRM event from precursor ion search". It means that in each analysis, in a sample with a pure compound, only a specific ion with a known molecular mass (determined by previous NMR analysis) was searched. The separation was achieved 
on the Kinetex column $(2.6 \mu \mathrm{M}$ C18 $100 \AA, 100 \mathrm{~mm} \times 3 \mathrm{~mm}$, Phenomenex, Torrance, CA, USA) operated at $30^{\circ} \mathrm{C}$. The mobile phase was a mixture of $0.1 \%$ aqueous formic acid $v / v$ (A) and acetonitrile (B). The gradient program was as follows: initial conditions- $-80 \% \mathrm{~B}$ in A, $6.5 \mathrm{~min}-100 \% \mathrm{~B}, 7 \mathrm{~min}-80 \% \mathrm{~B}$ in A. The flow rate was $0.4 \mathrm{~mL} \mathrm{~min}^{-1}$ and the injection volume was $5 \mu \mathrm{L}$. The principal operating parameters for the LC-MS were set as follows: nebulizing gas flow: $3 \mathrm{~L} \mathrm{~min}^{-1}$, heating gas flow: $10 \mathrm{~L} \mathrm{~min}^{-1}$, interface temperature: $30{ }^{\circ} \mathrm{C}$, drying gas flow: $10 \mathrm{~L} \mathrm{~min}^{-1}$, data acquisition range, $m / z$ 100-1000 Da; ionization mode, negative and positive. Data were collected with LabSolutions version 5.97 (Shimadzu, Kyoto, Japan) software.

\subsection{Screening Procedure}

The screening procedure was performed to assess time needed for the complete microbial transformation of substrate (3). As a growth medium for entomopathogenic filamentous fungi was used a modified Sabouraud medium $(10 \mathrm{~g}$ aminobac (purchased from BTL, Warsaw, Poland), $30 \mathrm{~g}$ saccharose (purchased from Chempur, Piekary Ślaskie, Poland), $1 \mathrm{~L}$ distilled water). Firstly, the culture of filamentous fungi strain was transferred from potato slants to a $300 \mathrm{~mL}$ Erlenmeyer flask with $100 \mathrm{~mL}$ of liquid medium. This preincubation culture was bred on a rotary shaker (DHN, Warsaw, Poland) (140 rpm) at $25^{\circ} \mathrm{C}$ for $72 \mathrm{~h}$. Secondly, the pre-grown culture $(0.5 \mathrm{~mL})$ was transferred to another $300 \mathrm{~mL}$ Erlenmeyer flask with $100 \mathrm{~mL}$ of liquid medium and also incubated for $72 \mathrm{~h}$ at $25^{\circ} \mathrm{C}$ on a rotary shaker (140 rpm). Afterward, $10 \mathrm{mg}$ of the substrate, $2^{\prime}$-hydroxy-2-methylchalcone (3), dissolved in $0.5 \mathrm{~mL}$ of dimethyl sulfoxide (Chempur, Piekary Ślaskie, Poland), was added to the flask. The molar concentration of substrate (3) was $0.42 \mathrm{mM}$. The samples were collected and extracted (with $30 \mathrm{~mL}$ of ethyl acetate) after 3, 6 and 9 days of incubating the substrate. All biotransformations were ended after confirming complete substrate conversion (or lack of further substrate conversion) after 9 days. The extracts were dried for five minutes with anhydrous magnesium sulfate (Chempur, Piekary Śląskie, Poland), concentrated using a rotary evaporator (Heidolph, Schwabach, Germany) at temperature $55^{\circ} \mathrm{C}$, and analyzed by TLC and HPLC methods. Two controls were performed: stability of the substrates under biotransformation conditions and microorganisms cultivation with no substrate added [34].

\subsection{The Semi-Preparative Biotransformations}

The semi-preparative biotransformations were performed in $2 \mathrm{~L}$ flasks with $500 \mathrm{~mL}$ of the modified Sabouraud medium each. For each biotransformation was used one flask. Firstly, $1 \mathrm{~mL}$ of the preincubation culture was transferred to the flask and incubated for $72 \mathrm{~h}$ under the same conditions as during the screening procedure. Afterward, $50 \mathrm{mg}$ of the substrate, $2^{\prime}$-hydroxy-2-methylchalcone (3), dissolved in $0.5 \mathrm{~mL}$ of dimethyl sulfoxide, was added and biotransformation was performed for 9 days. The molar concentration of substrates (3) was also $0.42 \mathrm{mM}$. The biotransformation was ended after confirming the complete substrate conversion (or lack of further substrate conversion). The metabolites were extracted two times (with $300 \mathrm{~mL}$ of ethyl acetate each time). The joined extracts were dried for five minutes with anhydrous magnesium sulfate and concentrated using a rotary evaporator. The products of biotransformation were separated using preparative TLC plates, and then analyzed by NMR, HPLC, and LC-MS [34].

The physical data, including color and form, melting point $\left({ }^{\circ} \mathrm{C}\right)$, molecular ion mass, molecular formula, retention time $t_{R}(\mathrm{~min})$,retardation factor $\mathrm{Rf}$, and NMR spectral data of the resulting compounds (3a-3e)are presented below, in Tables 1 and 2, and in the Supplementary Materials.

\subsubsection{2'-Hydroxy-2-methyldihydrochalcone 3'-O- $\beta$-D-(4"-O-Methyl)-glucopyranoside (3a)}

Light-yellow crystals, $\mathrm{mp}=80-81^{\circ} \mathrm{C}$, ESIMS $\mathrm{m} / \mathrm{z} 431.3\left([\mathrm{M}-\mathrm{H}]^{-}, \mathrm{C}_{23} \mathrm{H}_{28} \mathrm{O}_{8}\right)$, $t_{R}=11.74, \mathrm{Rf}=0.50,{ }^{1} \mathrm{H}-\mathrm{NMR}$, see Table $1,{ }^{13} \mathrm{C}-\mathrm{NMR}$, see Table 2, Supplementary Materials: Figures S19-S36. 
4.5.2. 2',3-Dihydroxy-2-methyldihydrochalcone 3'-O- $\beta$-D-(4'-O-Methyl)-glucopyranoside (3b)

Light-yellow crystals, $\mathrm{mp}=184-186^{\circ} \mathrm{C}$, ESIMS m/z $447.3\left([\mathrm{M}-\mathrm{H}]^{-}, \mathrm{C}_{23} \mathrm{H}_{28} \mathrm{O}_{9}\right)$, $\mathrm{t}_{\mathrm{R}}=5.45, \mathrm{Rf}=0.34,{ }^{1} \mathrm{H}-\mathrm{NMR}$, see Table $1,{ }^{13} \mathrm{C}-\mathrm{NMR}$, see Table 2, Supplementary Materials: Figures S37-S55).

4.5.3. $2^{\prime}$-Hydroxy-2-hydroxymethyldihydrochalcone 3'-O- $\beta$-D-( $4^{\prime \prime}$-O-Methyl)-glucopyranoside (3c)

Light-yellow crystals, $\mathrm{mp}=86-87^{\circ} \mathrm{C}$, ESIMS $\mathrm{m} / \mathrm{z} 447.3\left([\mathrm{M}-\mathrm{H}]^{-}, \mathrm{C}_{23} \mathrm{H}_{28} \mathrm{O}_{9}\right)$, $t_{R}=4.74, \mathrm{Rf}=0.31,{ }^{1} \mathrm{H}-\mathrm{NMR}$, see Table $1,{ }^{13} \mathrm{C}-\mathrm{NMR}$, see Table 2 , Supplementary Materials: Figures S56-S73.

4.5.4. 2' 4-Dihydroxy-2-methyldihydrochalcone 3'-O- $\beta$-D-(4'-O-Methyl)-glucopyranoside (3d)

Light-yellow crystals, $\mathrm{mp}=88-89^{\circ} \mathrm{C}$, ESIMS $\mathrm{m} / \mathrm{z} 447.3\left([\mathrm{M}-\mathrm{H}]^{-}, \mathrm{C}_{23} \mathrm{H}_{28} \mathrm{O}_{9}\right)$, $\mathrm{t}_{\mathrm{R}}=5.09, \mathrm{Rf}=0.33,{ }^{1} \mathrm{H}-\mathrm{NMR}$, see Table $1,{ }^{13} \mathrm{C}-\mathrm{NMR}$, see Table 2 , Supplementary Materials: Figures S74-S92.

4.5.5. 3-Hydroxy-2-methyldihydrochalcone 2'-O- $\beta$-D-(4"'-O-Methyl)-glucopyranoside (3e)

Light-yellow crystals, $\mathrm{mp}=55-56{ }^{\circ} \mathrm{C}$, ESIMS m/z $431.3\left([\mathrm{M}-\mathrm{H}]^{-}, \mathrm{C}_{23} \mathrm{H}_{28} \mathrm{O}_{8}\right)$, $\mathrm{t}_{\mathrm{R}}=5.58, \mathrm{Rf}=0.38,{ }^{1} \mathrm{H}-\mathrm{NMR}$, see Table $1,{ }^{13} \mathrm{C}-\mathrm{NMR}$, see Table 2 , Supplementary Materials: Figures S93-S109.

\section{Conclusions}

In this study, 2'-hydroxy-2-methylchalcone was synthesized and biotransformed in the cultures of three entomopathogenic filamentous fungi strains B. bassiana $\mathrm{KCH} \mathrm{J1.5,} \mathrm{I.}$

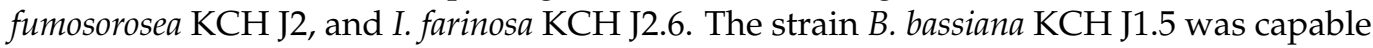
of the reduction of the double bond of 2'-hydroxy-2-methylchacone, its glycosylation at position $\mathrm{C}-3^{\prime}$, and hydroxylation at $\mathrm{C}-3, \mathrm{C}-4$ and $\mathrm{C} 2-\mathrm{CH}_{3}$. It can be assumed that the presence of the hydroxyl moiety at $\mathrm{C}-2^{\prime}$ is responsible for the directing effect on glycosylation at position $\mathrm{C}-3^{\prime}$. The strain I. farinosa $\mathrm{KCH} \mathrm{J} 2.6$ also formed dihydrochalcones with $4^{\prime \prime}-\mathrm{O}-$ methyl-glycosyl group at $\mathrm{C}^{-3^{\prime}}$ and hydroxylated at C-3. The last strain I. fumosorosea $\mathrm{KCH}$ $\mathrm{J} 2$ was capable of the reduction of the double bond of 2'-hydroxy-2-methylchacone and its glycosylation at $\mathrm{C}-2^{\prime}$. In all formed products, the methyl moiety at C-2 remained intact. All the above-mentioned biotransformation products have not been previously described in the literature. Their biological activity and bioavailability can be assessed in further in vitro and in vivo studies. Above and beyond, dihydrochalcones may be considered as flavor enhancers and potential sweeteners.

Supplementary Materials: The following are available online at https:/ /www.mdpi.com/article/10 $.3390 /$ ijms22179619/s1.

Author Contributions: Conceptualization, A.K.-Ł. and E.K.-S.; methodology, A.K.-Ł., E.K.-S. and M.D.; validation, A.K.-Ł.; formal analysis, A.K.-Ł., E.K.-S., M.D. and T.J.; investigation, A.K.-Ł.; resources, E.K.-S.; data curation, A.K.-Ł. and E.K.-S.; writing-original draft preparation, A.K.-Ł.; writing-review and editing, A.K.-Ł., E.K.-S. and M.D.; visualization, A.K.-Ł.; supervision, E.K.-S.; project administration, A.K.-Ł. and E.K.-S.; funding acquisition, A.K.-Ł. and E.K.-S. All authors have read and agreed to the published version of the manuscript.

Funding: This research received no external funding.

Data Availability Statement: Samples of the compounds 3, 3a-3e are available from the authors.

Acknowledgments: Article Processing Charge (APC) was financed under the Leading Research Groups support project from the subsidy increased for the period 2020-2025 in the amount of $2 \%$ of the subsidy referred to Art. 387 (3) of the Law of 20 July 2018 on Higher Education and Science, obtained in 2019.

Conflicts of Interest: The authors declare no conflict of interest. 


\section{References}

1. Crozier, A.; Jaganath, I.B.; Clifford, M.N. Dietary phenolics: Chemistry, bioavailability and effects on health. Nat. Prod. Rep. 2009, 26, 1001-1043. [CrossRef]

2. Cassidy, A.; Minihane, A.M. The role of metabolism (and the microbiome) in defining the clinical efficacy of dietary flavonoids. Am. J. Clin. Nutr. 2017, 105, 10-22. [CrossRef]

3. Perez-Vizcaino, F.; Fraga, C.G. Research trends in flavonoids and health. Arch. Biochem. Biophys. 2018, 646, 107-112. [CrossRef]

4. Wang, T.Y.; Li, Q.; Bi, K. Bioactive flavonoids in medicinal plants: Structure, activity and biological fate. Asian J. Pharm. Sci. 2018, 13, 12-23. [CrossRef]

5. Stompor, M.; Kałużny, M.; Żarowska, B. Biotechnological methods for chalcone reduction using whole cells of Lactobacillus, Rhodococcus and Rhodotorula strains as a way to produce new derivatives. Appl. Microbiol. Biotechnol. 2016, 100, 8371-8384. [CrossRef]

6. Zhang, J.; Fu, X.L.; Yang, N.; Wang, Q.A. Synthesis and cytotoxicity of chalcones and 5-deoxyflavonoids. Sci. World J. 2013, 2013, 649485. [CrossRef] [PubMed]

7. Nagula, R.L.; Wairkar, S. Recent advances in topical delivery of flavonoids: A review. J. Control. Release 2019, $296,190-201$. [CrossRef] [PubMed]

8. Thilakarathna, S.H.; Rupasinghe, V.H.P. Flavonoid bioavailability and attempts for bioavailability enhancement. Nutrients 2013, 5, 3367-3387. [CrossRef]

9. Koirala, N.; Thuan, N.H.; Ghimire, G.P.; Thang, D.V.; Sohng, J.K. Methylation of flavonoids: Chemical structures, bioactivities, progress and perspectives for biotechnological production. Enzym. Microb.Technol. 2016, 86, 103-116. [CrossRef]

10. Wen, L.; Jiang, Y.; Yang, J.; Zhao, Y.; Tian, M.; Yang, B. Structure, bioactivity, and synthesis of methylated flavonoids. Ann. N. Y. Acad. Sci. 2017, 1398, 120-129. [CrossRef] [PubMed]

11. Xiao, J.; Muzashvili, T.S.; Georgiev, M.I. Advances in the biotechnological glycosylation of valuable flavonoids. Biotechnol. Adv. 2014, 32, 1145-1156. [CrossRef]

12. Dymarska, M.; Janeczko, T.; Kostrzewa-Susłow, E. Glycosylation of 3-hydroxyflavone, 3-methoxyflavone, quercetin and baicalein in fungal cultures of the genus Isaria. Molecules 2018, 23, 2477. [CrossRef] [PubMed]

13. Xiao, J. Dietary flavonoid aglycones and their glycosides: Which show better biological significance? Crit. Rev. Food. Sci. Nutr. 2017, 57, 1874-1905. [CrossRef] [PubMed]

14. Hostetler, G.L.; Ralston, R.A.; Schwartz, S.J. Flavones: Food sources, bioavailability, metabolism, and bioactivity. Adv. Nutr. 2017, 8, 423-435. [CrossRef] [PubMed]

15. Janeczko, T.; Gładkowski, W.; Kostrzewa-Susłow, E. Microbial transformations of chalcones to produce food sweetener derivatives. J. Mol. Catal. B Enzym. 2013, 98, 55-61. [CrossRef]

16. Ruiz-Ojeda, F.J.; Plaza-Díaz, J.; Sáez-Lara, M.J.; Gil, A. Effects of sweeteners on the gut microbiota: A review of experimental studies and clinical trials. Adv. Nutr. 2019, 10, S31-S48. [CrossRef] [PubMed]

17. Yang, W.; Zhou, K.; Zhou, Y.; An, Y.; Hu, T.; Lu, J.; Huang, S.; Pei, G. Naringin dihydrochalcone ameliorates cognitive deficits and neuropathology in APP/PS1 transgenic mice. Front. Aging Neurosci. 2018, 10, 169. [CrossRef] [PubMed]

18. Ehrenkranz, J.R.L.; Lewis, N.G.; Kahn, C.R.; Roth, J. Phlorizin: A review. Diabetes Metab. Res. Rev. 2005, 21, 31-38. [CrossRef]

19. Londzin, P.; Siudak, S.; Cegieła, U.; Pytlik, M.; Janas, A.; Waligóra, A.; Folwarczna, J. Phloridzin, an apple polyphenol, exerted unfavorable effects on bone and muscle in an experimental model of type 2 diabetes in rats. Nutrients 2018, 10, 1701. [CrossRef]

20. Payne, J.N.; Badwaik, V.D.; Waghwani, H.K.; Moolani, H.V.; Tockstein, S.; Thompson, D.H.; Dakshinamurthy, R. Development of dihydrochalcone-functionalized gold nanoparticles for augmented antineoplastic activity. Int. J. Nanomed. 2018, 13, 1917-1926. [CrossRef]

21. Niederberger, K.E.; Tennant, D.R.; Bellion, P. Dietary intake of phloridzin from natural occurrence in foods. Br. J. Nutr. 2020, 123, 942-950. [CrossRef]

22. Tian, L.; Cao, J.; Zhao, T.; Liu, Y.; Khan, A.; Cheng, G. The bioavailability, extraction, biosynthesis and distribution of natural dihydrochalcone: Phloridzin. Int. J. Mol. Sci. 2021, 22, 962. [CrossRef]

23. Hofer, B. Recent developments in the enzymatic O-glycosylation of flavonoids. Appl. Microbiol. Biotechnol. 2016, $100,4269-4281$. [CrossRef] [PubMed]

24. Nakamura, Y.; Watanabe, S.; Miyake, N.; Kohno, H.; Osawa, T. Dihydrochalcones: Evaluation as novel radical scavenging antioxidants. J. Agric. Food Chem. 2003, 51, 3309-3312. [CrossRef]

25. Xiao, Z.; Wang, Y.; Wang, J.; Li, P.; Ma, F. Structure-antioxidant capacity relationship of dihydrochalcone compounds in Malus. Food Chem. 2019, 275, 354-360. [CrossRef] [PubMed]

26. Wu, S.Y.; Fu, Y.H.; Zhou, Q.; Bai, M.; Chen, G.Y.; Han, C.R.; Song, X.P. A new dihydrochalcone glycoside from the stems of Homalium stenophyllum. Nat. Prod. Res. 2018, 32, 953-958. [CrossRef] [PubMed]

27. Omar, A.M.; Dibwe, D.F.; Sun, S.; Tawila, A.M.; Kim, M.; Phrutivorapongkul, A.; Toyooka, N.; Awale, S. Fragranone C: A new dihydrochalcone glucopyranoside from Anneslea fragrans twigs. Nat. Prod. Res. 2020, 2, 1-6. [CrossRef]

28. Bao, S.; Wang, Q.; Bao, W.; Ao, W. Structure elucidation and NMR assignments of a new dihydrochalcone from Empetrum nigrum subsp. asiaticum (Nakai ex H.Ito) Kuvaev. Nat. Prod. Res. 2020, 34, 930-934. [CrossRef] 
29. Pompermaier, L.; Heiss, E.H.; Alilou, M.; Mayr, F.; Monizi, M.; Lautenschlaeger, T.; Schuster, D.; Schwaiger, S.; Stuppner, H. Dihydrochalcone Glucosides from the Subaerial Parts of Thonningia sanguinea and Their in Vitro PTP1B Inhibitory Activities. J. Nat. Prod. 2018, 81, 2091-2100. [CrossRef] [PubMed]

30. Lima, E.M.; Fernando, L.M.; Felix, L.P.; de Oliveira Filho, A.A.; Carneiro Neto, A.N.; Moura, R.T.; Teles, Y.C.F. First complete NMR data and theoretical study of an antimicrobial formylated dihydrochalcone from Psidium guineense Sw. Nat. Prod. Res. 2020, 1-5. [CrossRef]

31. Dymarska, M.; Janeczko, T.; Kostrzewa-Susłow, E. Glycosylation of methoxylated flavonoids in the cultures of Isaria fumosorosea KCH J2. Molecules 2018, 23, 2578. [CrossRef] [PubMed]

32. Dymarska, M.; Janeczko, T.; Kostrzewa-Susłow, E. Biotransformations of flavones and an isoflavone (daidzein) in cultures of entomopathogenic filamentous fungi. Molecules 2018, 23, 1356. [CrossRef]

33. Dymarska, M.; Grzeszczuk, J.; Urbaniak, M.; Janeczko, T.; Pląskowska, E.; Stępień, Ł.; Kostrzewa-Susłow, E. Glycosylation of 6-methylflavone by the strain Isaria fumosorosea KCH J2. PLoS ONE 2017, 12, e0184885. [CrossRef]

34. Krawczyk-Łebek, A.; Dymarska, M.; Janeczko, T.; Kostrzewa-Susłow, E. Entomopathogenic filamentous fungi as biocatalysts in glycosylation of methylflavonoids. Catalysts 2020, 10, 1148. [CrossRef]

35. Dou, F.; Wang, Z.; Li, G.; Dun, B. Microbial transformation of flavonoids by Isaria fumosorosea ACCC 37814. Molecules 2019, 24, 1028. [CrossRef] [PubMed]

36. Sordon, S.; Popłoński, J.; Tronina, T.; Huszcza, E. Regioselective O-glycosylation of flavonoids by fungi Beauveria bassiana, Absidia coerulea and Absidia glauca. Bioorg. Chem. 2019, 93, 102750. [CrossRef]

37. Sordon, S.; Popłoński, J.; Tronina, T.; Huszcza, E. Microbial glycosylation of daidzein, genistein and biochanin a: Two new glucosides of biochanin A. Molecules 2017, 22, 81. [CrossRef]

38. Strugała, P.; Tronina, T.; Huszcza, E.; Gabrielska, J. Bioactivity in vitro of quercetin glycoside obtained in Beauveria bassiana culture and its interaction with liposome membranes. Molecules 2017, 22, 1520. [CrossRef] [PubMed]

39. Tronina, T.; Strugała, P.; Popłoński, J.; Włoch, A.; Sordon, S.; Bartmańska, A.; Huszcza, E. The Influence of Glycosylation of Natural and Synthetic Prenylated Flavonoids on Binding to Human Serum Albumin and Inhibition of Cyclooxygenases COX-1 and COX-2. Molecules 2017, 22, 1230. [CrossRef]

40. Kozłowska, E.; Urbaniak, M.; Hoc, N.; Grzeszczuk, J.; Dymarska, M.; Stępień, Ł.; Pląskowska, E.; Kostrzewa-Susłow, E.; Janeczko, T. Cascade biotransformation of dehydroepiandrosterone (DHEA) by Beauveria species. Sci. Rep. 2018, 8, 13449. [CrossRef]

41. Łużny, M.; Tronina, T.; Kozłowska, E.; Dymarska, M.; Popłoński, J.; Łyczko, J.; Kostrzewa-Susłow, E.; Janeczko, T. Biotransformation of methoxyflavones by selected entomopathogenic filamentous fungi. Int. J. Mol. Sci. 2020, 21, 6121. [CrossRef]

42. Kim, H.J.; Lee, I.S. Microbial metabolism of the prenylated chalcone xanthohumol. J. Nat. Prod. 2006, 69, 1522-1524. [CrossRef]

43. Tronina, T.; Bartmańska, A.; Milczarek, M.; Wietrzyk, J.; Popłoński, J.; Rój, E.; Huszcza, E. Antioxidant and antiproliferative activity of glycosides obtained by biotransformation of xanthohumol. Bioorg. Med. Chem. Lett. 2013, 23, 1957-1960. [CrossRef]

44. Huszcza, E.; Bartmańska, A.; Tronina, T. Glycosylation of xanthohumol by fungi. Z. Naturforsch. C J. Biosci. 2008, 63, 557-560. [CrossRef]

45. Overwin, H.; Wray, V.; Hofer, B. Biotransformation of phloretin by amylosucrase yields three novel dihydrochalcone glucosides. J. Biotechnol. 2015, 211, 103-106. [CrossRef] [PubMed]

46. Kostrzewa-Susow, E.; Dymarska, M.; Guzik, U.; Wojcieszyńska, D.; Janeczko, T. Stenotrophomonas maltophilia: A gram-negative bacterium useful for transformations of flavanone and chalcone. Molecules 2017, 22, 1830. [CrossRef] [PubMed]

47. Żyszka-Haberecht, B.; Poliwoda, A.; Lipok, J. Structural constraints in cyanobacteria-mediated whole-cell biotransformation of methoxylated and methylated derivatives of 2'-hydroxychalcone. J. Biotechnol. 2019, 293, 36-46. [CrossRef] [PubMed]

48. Łużny, M.; Kozłowska, E.; Kostrzewa-Susłow, E.; Janeczko, T. Highly effective, regiospecific hydrogenation of methoxychalcone by Yarrowia lipolytica enables production of food sweeteners. Catalysts 2020, 10, 1135. [CrossRef]

49. Silva, V.D.; Stambuk, B.U.; da Graca Nascimento, M. Efficient chemoselective biohydrogenation of 1,3-diaryl-2-propen-1-ones catalyzed by Saccharomyces cerevisiae yeasts in biphasic system. J. Mol. Catal. B Enzym. 2010, 63, 157-163. [CrossRef]

50. Silva, A.M.S.; Tavares, H.R.; Barros, A.I.N.R.A.; Cavaleiro, J.A.S. NMR and structural and conformational features of 2' hydroxychalcones and flavones. Spectrosc. Lett. 1997, 30, 1655-1667. [CrossRef]

51. Yadav, N.; Dixit, S.K.; Bhattacharya, A.; Mishra, L.C.; Sharma, M.; Awasthi, S.K.; Bhasin, V.K. Antimalarial activity of newly synthesized chalcone derivatives in vitro. Chem. Biol. Drug Des. 2012, 80, 340-347. [CrossRef] [PubMed] 